\title{
Application of Cluster Analysis in Assessment of Dietary Habits of Secondary School Students
}

\author{
Magdalena Zalewska ${ }^{1}$, Jacek Jamiołkowski ${ }^{1}$, Agnieszka Genowska ${ }^{1}$, \\ Ewa Rodakowska ${ }^{2}$, Andrzej Szpak ${ }^{1}$, Elżbieta Maciorkowska ${ }^{3}$ \\ 1 Department of Public Health, Medical University of Bialystok, Poland \\ 2 Department of Restorative Dentistry, Medical University of Bialystok, Poland \\ 3 Department of Developmental Age Medicine and Paediatric Nursing, Medical University \\ of Bialystok, Poland
}

\begin{abstract}
Maintenance of proper health and prevention of diseases of civilization are now significant public health problems. Nutrition is an important factor in the development of youth, as well as the current and future state of health. The aim of the study was to show the benefits of the application of cluster analysis to assess the dietary habits of high school students. The survey was carried out on 1,631 eighteen-year-old students in seven randomly selected secondary schools in Bialystok using a self-prepared anonymous questionnaire. An evaluation of the time of day meals were eaten and the number of meals consumed was made for the surveyed students. The cluster analysis allowed distinguishing characteristic structures of dietary habits in the observed population. Four clusters were identified, which were characterized by relative internal homogeneity and substantial variation in terms of the number of meals during the day and the time of their consumption. The most important characteristics of cluster 1 were cumulated food ration in 2 or 3 meals and long intervals between meals. Cluster 2 was characterized by eating the recommended number of 4 or 5 meals a day. In the $3^{\text {rd }}$ cluster, students ate 3 meals a day with large intervals between them, and in the $4^{\text {th }}$ they had four meals a day while maintaining proper intervals between them. In all clusters dietary mistakes occurred, but most of them were related to clusters 1 and 3. Cluster analysis allowed for the identification of major flaws in nutrition, which may include irregular eating and skipping meals, and indicated possible connections between eating patterns and disturbances of body weight in the examined population.
\end{abstract}

\section{Introduction}

The maintenance of proper health and prevention of diseases of civilization are now significant public health problems. Improper lifestyle in early childhood and adolescence may adversely affect health in the future (Bagińska et al., 2012; Krawczyńska et al., 2013; Ponczek et al., 2012). Diet 
is one of the most important lifestyle determinants of health. Both deficiency and excess of energy supply and nutrients adversely affect the nutritional status of the body.

The epidemic of obesity, which increasingly draws the attention of the World Health Organization, affects not only adults, but also children and adolescents (WHO, 2012). According to NHANES research from the years 2009-2010, obesity affects one-third of adults and almost $17 \%$ of children and adolescents (Ogden et al., 2012).

The OLAF survey, conducted among children and adolescents of school age, revealed that $14 \%$ of girls and $18 \%$ of boys were overweight or obese, and total weight deficiency occurred in $12 \%$ (10\% of boys and $13.7 \%$ girls) (Kułaga et al., 2011). It is a significant concern that a large proportion of obese children remain obese as adults (Pelone et al., 2012; Speiser et al., 2005).

Improper diet significantly contributes to the development and severity of diseases such as type 2 diabetes, hypertension, stroke, and coronary heart disease, leading to reduction in length and quality of life (Baker et al., 2010; Kardasz et al., 2008). In the year 2014, overweight and obesity were responsible for the deaths of 3.4 million people in the world, which was associated with a loss of $3.9 \%$ years of life and $3.8 \%$ disability adjusted years of life (DALY) (Ng et al., 2014).

One of the criteria for assessing the quality of diet is regularity - the number and timing of food intake. Direct analysis of hours of food intake using classical statistical methods encountered difficulties. If the hours of eating each meal were treated as independent variables, it would result in a set of data with many shortcomings due to the fact that only a small percentage of respondents ate all the meals. As a result, direct analysis of meal times would entail exclusion of a significant percentage of the respondents.

The aim of the study was to show the benefits of the application of the method of cluster analysis to assess dietary habits among groups of high school students.

\section{Material and Methods}

The survey was carried out on 1,631 eighteen-year-old students in seven randomly selected secondary schools in Bialystok using a self-prepared anonymous questionnaire during the 2008/2009 school year. The questionnaire contained questions about selected dietary habits, for instance the 
number and type of consumed meals, frequency of consumption, snacking between meals, and the assessment of diet. Girls accounted for $64.5 \%$ (1051), and boys $35.5 \%$ (580) of respondents. The research was conducted in collaboration with the Board of Education in Bialystok. Prior to the survey, the students were informed about the purposes and methods of research. Each student agreed to join the study by filling out a specially prepared form. The questionnaire was approved by the Bioethics Committee of the Medical University of Bialystok.

Proper research was preceded by a pilot study to check the organization of research, its course and the students' understanding of the questions in the questionnaire. The pilot study was carried out in a group of 60 students attending secondary schools in Bialystok.

The weight and height of the young people were measured to calculate the growth rate of weight-BMI (Body Mass Index) of the young people as the ratio of weight in kilograms and height in meters squared according to the formula:

$$
B M I=\frac{\operatorname{mass}(k g)}{(h e i g h t(m))^{2}}
$$

BMI values of the young people were interpreted by comparison with centile growth charts of BMI for boys and girls aged eighteen years. Among the surveyed students, different groups were distinguished in terms of nutritional status, based on BMI: students with deficient body weight, eutrophic students and students with excessive body weight, the overweight and obese.

The study presented an evaluation of the times and numbers of meals the surveyed students consumed. The aim was to identify the characteristic structures of meals in this population by using cluster analysis. The source data for the analysis were the time of consumption of individual meals ( $1^{\text {st }}$ breakfast, $2^{\text {nd }}$ breakfast, dinner, afternoon tea, supper) on the day preceding the survey. In many cases, there were missing data due to the large number of variations in the configuration of meals taken by the respondents. According to the direct method, we could use only data from people consuming all meals, which would obviously lead to an unrepresentative subgroup analysis. To avoid this limitation, artificial indicators were introduced which described a daily schedule of meals in a synthetic way and could be computed regardless of number of consumed meals. Seven indicators were used in total: time of the first and last meal, the length of the night break between meals (the difference between the first and the last meal), the number of meals, the average interval between meals (arithmetic mean of the distances between meals; set to 24 hours when a person con- 
sumed only one meal a day), as well as the minimum and maximum interval between meals.

The above-described indicators were used to identify clusters of persons with similar dietary habits. The clustering was conducted using the TwoStep Clustering method available in IBM $^{\circledR}$ SPSS $^{\circledR}$ Statistics software. The aim of the clustering algorithm was to minimize within-cluster variability, while maximizing between-cluster variability. Log-likelihood was chosen as a distance measure between individual data vectors. The optimal number of clusters was selected automatically by a clustering algorithm based on Schwarz's Bayesian Information Criterion (BIC).

Identified clusters were compared regarding distributions of a number of categorical variables. The relationship between the cluster membership variable and those categorical variables were evaluated with Pearson's $\chi^{2}$ test. This test was extended with the $\mathrm{z}$ test for two proportions, which allowed for pairwise comparisons. Results of these tests were adjusted for multiple comparisons using Bonferroni adjustment to keep type I error at the same level as for Pearson's $\chi^{2}$ test. All statistical hypotheses were verified at a significance level of $\alpha=0.05$.

\section{Results}

It has been shown that $78.3 \%$ of girls and $77.9 \%$ of boys were among eutrophic students (BMI between 5 and 85 percentiles). In $10.5 \%$ of girls and $4.1 \%$ of boys $(p<0.001)$ nutritional disorders presented as a weight deficiency (BMI below the $5^{\text {th }}$ percentile) were observed. Overweight was present in $8.7 \%$ of girls and $10.2 \%$ boys. $2.5 \%$ of girls and $7.8 \%$ of boys $(p<0.001)$ were classified as obese. Table 1 presents the assessment of BMI in the examined group of students according to sex.

Table 1. The assessment of BMI in the examined group of students according to sex

\begin{tabular}{|l|r|r|r|r|c|}
\hline \multirow{2}{*}{ BMI category } & \multicolumn{2}{|c|}{ girls } & \multicolumn{2}{c|}{ boys } & \multirow{2}{*}{ Statistical significance } \\
\cline { 2 - 5 } & \multicolumn{1}{|c|}{$\mathrm{N}$} & \multicolumn{1}{c|}{$(\%)$} & \multicolumn{1}{c|}{$\mathrm{N}$} & \multicolumn{1}{c|}{$(\%)$} & \\
\hline$<5$ centile weight deficiency & 111 & 10.5 & 24 & 4.1 & $p<0.001$ \\
{$[5-85)$ centile norm } & 823 & 78.3 & 452 & 77.9 & NS \\
{$[85-95)$ centile overweight } & 91 & 8.7 & 59 & 10.2 & NS \\
$\geq 85$ centile obesity & 26 & 2.5 & 45 & 7.8 & $p<0.001$ \\
\hline total & 1051 & 100.0 & 580 & 100.0 & - \\
\hline
\end{tabular}


Four clusters were distinguished, which were characterized with relative within-cluster homogeneity and substantial between-cluster variability in terms of the number of meals during the day and time of consumption (Table 2).

Table 2. Characteristics of clusters with respect to the number of meals during the day and the time of consumption

\begin{tabular}{|l|l|c|c|c|c|c|}
\hline \multicolumn{2}{|c|}{ Characteristics of clusters } & Mean & SD & Minimum & Median & Maximum \\
\hline First meal & cluster 1 & 9.1 & 3.1 & 5.3 & 7.5 & 19.0 \\
& cluster 2 & 7.3 & 1.9 & 4.5 & 7.0 & 21.0 \\
& cluster 3 & 7.2 & 1.0 & 5.5 & 7.0 & 11.0 \\
& cluster 4 & 7.5 & 1.2 & 5.8 & 7.3 & 13.0 \\
\hline Last meal & cluster 1 & 18.0 & 2.2 & 10.0 & 18.0 & $25.0^{*}$ \\
& cluster 2 & 20.0 & 2.5 & 6.5 & 20.0 & $25.0^{*}$ \\
& cluster 3 & 19.9 & 1.5 & 17.0 & 20.0 & 26.5 \\
& cluster 4 & 19.0 & 1.2 & 16.5 & 19.0 & $25.0^{*}$ \\
\hline Night break & cluster 1 & 15.1 & 2.8 & 7.0 & 15.0 & 22.0 \\
& cluster 2 & 11.3 & 3.3 & 6.0 & 11.0 & 24.0 \\
& cluster 3 & 11.3 & 1.4 & 7.0 & 11.7 & 13.7 \\
& cluster 4 & 12.5 & 1.3 & 6.0 & 12.5 & 17.0 \\
\hline Number of meals & cluster 1 & 2.6 & 0.5 & 2.0 & 3.0 & 3.0 \\
& cluster 2 & 4.3 & 1.0 & 1.0 & 4.0 & 5.0 \\
& cluster 3 & 3.0 & 0.1 & 3.0 & 3.0 & 4.0 \\
& cluster 4 & 4.1 & 0.5 & 2.0 & 4.0 & 5.0 \\
\hline Average interval & cluster 1 & 5.9 & 2.5 & 1.5 & 5.0 & 16.5 \\
between meals & cluster 2 & 5.2 & 4.8 & 3.0 & 4.2 & 24.0 \\
& cluster 3 & 6.3 & 0.7 & 5.2 & 6.2 & 8.5 \\
& cluster 4 & 3.7 & 0.8 & 2.3 & 3.8 & 11.0 \\
\hline Minimum interval & cluster 1 & 5.0 & 3.0 & 0.0 & 4.0 & 16.5 \\
between meals & cluster 2 & 3.8 & 5.2 & 0.5 & 2.5 & 24.0 \\
& cluster 3 & 4.2 & 1.4 & 0.0 & 4.0 & 8.0 \\
\hline Maximum interval & cluster 4 & 2.4 & 0.9 & 0.5 & 2.5 & 11.0 \\
between meals & cluster 1 & 6.8 & 2.6 & 2.0 & 6.0 & 16.5 \\
& cluster 2 & 6.9 & 4.5 & 3.5 & 5.5 & 24.0 \\
& cluster 3 & 8.4 & 1.3 & 5.5 & 8.5 & 13.0 \\
& 5.3 & 1.4 & 3.0 & 5.0 & 14.0 \\
\hline
\end{tabular}

* Number of hours exceeding 24 means the meals were consumed the next day

Cluster 1 was characterized by late consumption of breakfast (after 9 a.m.), and the relatively early consumption of the last meal of the day (6 p.m.). The night break between meals was more than 15 hours. People belonging to this cluster had 2 or 3 meals a day, with an average inter- 
val between each meal of almost 6 hours ( 5 hours and 54 minutes). The minimum interval between meals was 5 hours, and the maximum time was 6 hours and 48 minutes. In cluster 2, students had breakfast after 7 a.m. and the last meal of the day at 8 p.m. The night break between meals was 11 hours and 20 minutes. Students belonging to this cluster usually consumed 4 or 5 meals a day, and the average interval between the meals was 5 hours and 12 minutes. The minimum interval between meals was 3 hours and 48 minutes, and the maximum was 6 hours and 54 minutes. Cluster 3 was characterized by consumption of breakfast after 7 a.m., and the last meal of the day before 8 p.m. The night break between meals was 11 hours and 20 minutes. Students belonging to cluster had 3 meals, with an average interval between meals of 6 hours and 18 minutes. There were large fluctuations in the intervals between meals (4 hours and 12 minutes to 8 hours and 24 minutes) in this cluster. In cluster 4 , breakfasts were at 7:30 a.m. The last meal of the day was at 7 p.m. The night break between meals was 12 hours and 30 minutes. Students belonging to this cluster had 4 meals a day, with an average interval between meals of 3 hours and 28 minutes. The minimum break between meals was 2 hours and 24 minutes, and the maximum was 5 hours and 18 minutes.

In conclusion, the most important feature of cluster 1 was the accumulation of food ratios in 2 or 3 meals with long intervals between them. Cluster 2 was characterized by eating the recommended number of 4 or 5 meals a day. Cluster 3 was characterized by eating 3 meals a day with large intervals between them, and in cluster 4, 4 meals a day while maintaining proper intervals between them. Clusters 2 and 4 were characterized by better ways of nutrition according to the analysed parameters.

Among the surveyed students, differences were observed in terms of nutritional status: students with malnutrition, eutrophic students and students with overweight and obesity. Most students with low BMIs were in cluster $2(10.6 \%)$, and the fewest were in cluster $4(5.9 \%)$; the difference between these clusters was statistically significant $(p<0.05)$. The fewest students with regular weight were found in cluster $1(75.1 \%)$. In clusters 2 , 3 and 4 , the percentages were higher $(79.6 \%, 79.9 \%$ and $80.3 \%)$; a statistically significant difference was found between clusters 1 and 2 . At the same time, in cluster 1 the greatest number of people with overweight and obesity $(16.9 \%)$ was observed, while the least were observed in cluster $2(9.7 \%)$ (Table 3).

The sex of examined students was taken into consideration. In clusters 1 and 4 , there were significantly more girls $(73.5 \%$ and $70.5 \%$ respectively) 
Application of Cluster Analysis in Assessment of Dietary Habits...

Table 3. BMI of surveyed students in separate clusters

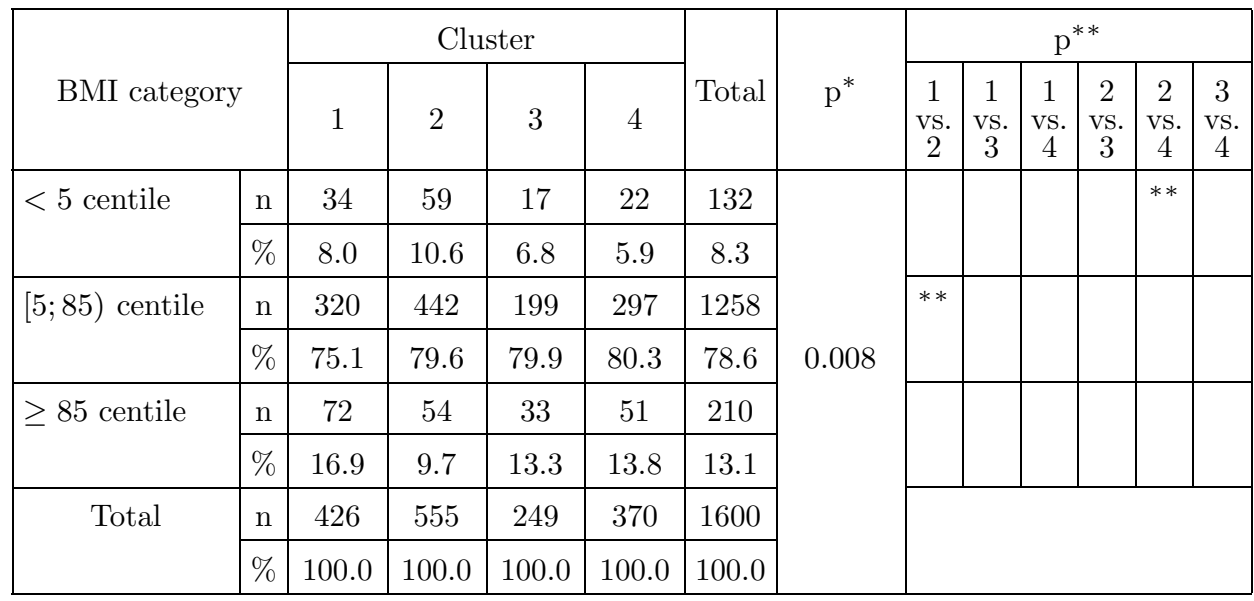

* Pearson's $\chi^{2}$ independence test

** Test for two proportions with a Bonferroni correction for multiple comparisons, $p<0.05$

Table 4. Sex of surveyed students in separate clusters

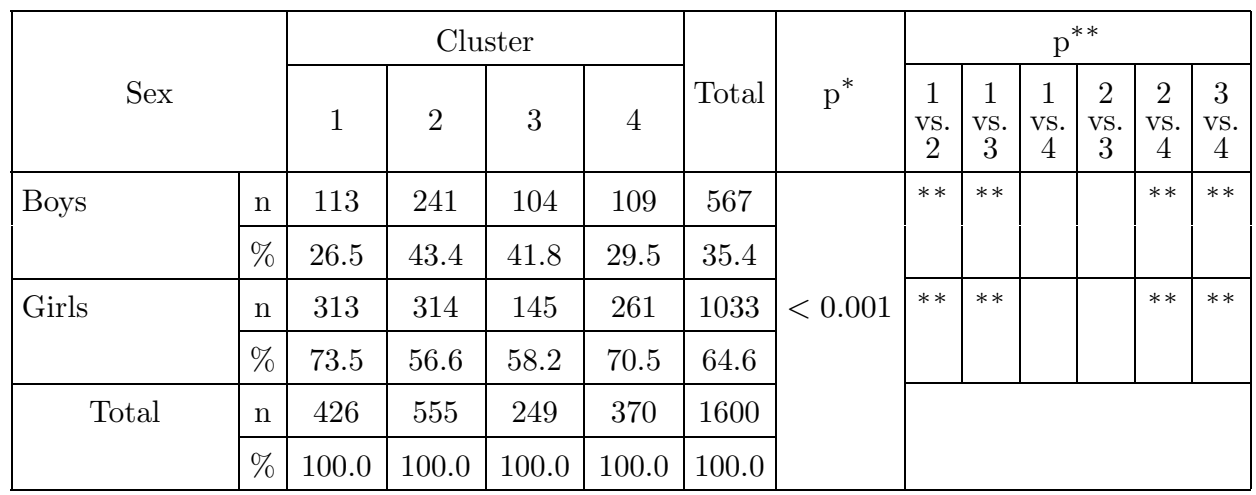

* Pearson's $\chi^{2}$ independence test

** Test for two proportions with a Bonferroni correction for multiple comparisons, $p<0.05$

than boys compared to clusters 2 and 3 (56.6\% and $58.2 \%$ respectively) (Table 4).

We analysed the usual dietary habits of various meals consumed throughout the day by the surveyed students. Cluster 1 was characterized by a low percentage of students consuming a $1^{\text {st }}$ breakfast compared to other clusters. Second breakfast, dinner, and afternoon tea were consumed mostly by students belonging to clusters 2 and 4 . Lack of eating supper was frequently declared by students in cluster 1 (Table 5 ). 
Magdalena Zalewska et al.

Table 5. Frequency of usual consumption of individual meals in separate clusters

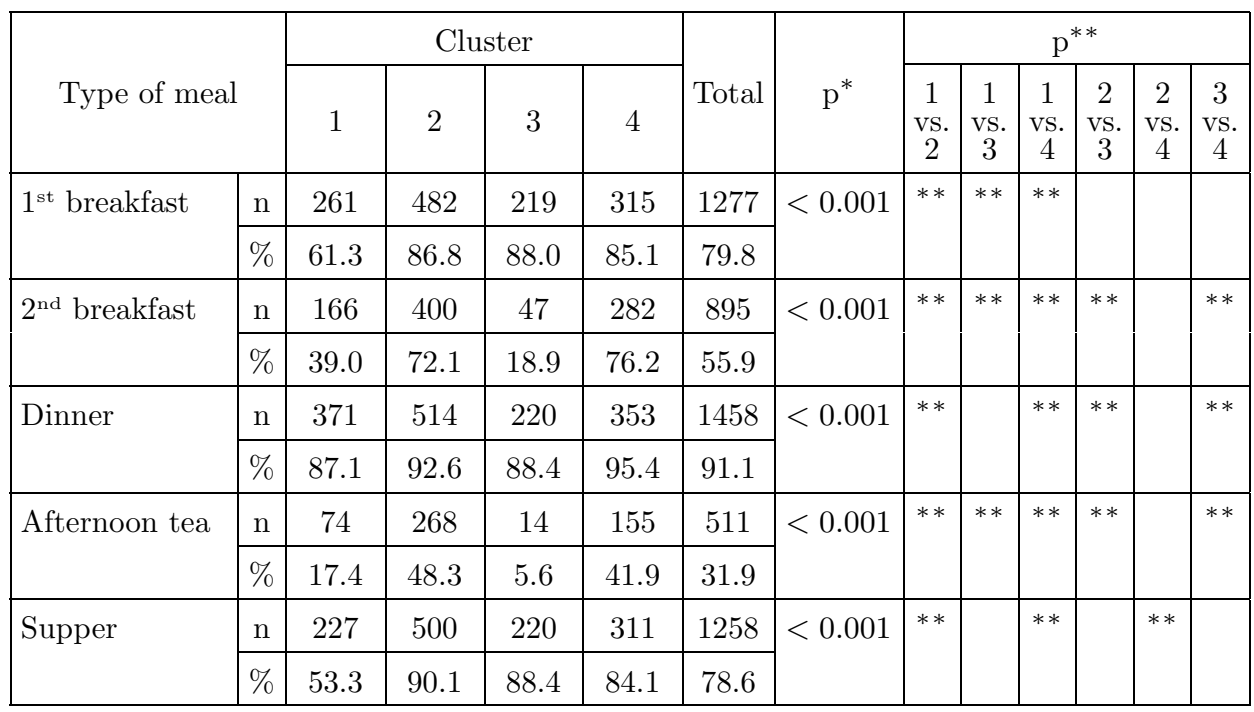

* Pearson's $\chi^{2}$ independence test

** Test for two proportions with a Bonferroni correction for multiple comparisons, $p<0.05$

Snacking between meals was a phenomenon present in the diet of $96.2 \%$ of high school students in Bialystok. Students belonging to cluster 1 were the least likely to snack between meals, while the most frequently snacking students belonged to cluster $2, p<0.05$ (Table 6).

Table 6. Snacking between meals among the surveyed students in separate clusters

\begin{tabular}{|c|c|c|c|c|c|c|c|c|c|c|c|c|c|}
\hline \multirow{2}{*}{\multicolumn{2}{|c|}{$\begin{array}{c}\text { Do you snack } \\
\text { between meals? }\end{array}$}} & \multicolumn{4}{|c|}{ Cluster } & \multirow[b]{2}{*}{ Total } & \multirow[b]{2}{*}{$\mathrm{p}^{*}$} & \multicolumn{6}{|c|}{$\mathrm{p}^{* *}$} \\
\hline & & \multirow{2}{*}{$\begin{array}{c}1 \\
148\end{array}$} & \multirow{2}{*}{$\begin{array}{c}2 \\
328\end{array}$} & \multirow{2}{*}{$\begin{array}{c}3 \\
106\end{array}$} & \multirow{2}{*}{$\begin{array}{c}4 \\
153\end{array}$} & & & $\begin{array}{c}1 \\
\text { vs. } \\
?\end{array}$ & $\begin{array}{c}1 \\
\text { vs. }\end{array}$ & $\begin{array}{c}1 \\
\text { vs. }\end{array}$ & $\begin{array}{c}2 \\
\text { vs. } \\
3\end{array}$ & $\begin{array}{c}2 \\
\text { vs. } \\
4\end{array}$ & $\begin{array}{c}3 \\
\text { vs. }\end{array}$ \\
\hline Yes, often & $\mathrm{n}$ & & & & & 735 & \multirow{8}{*}{$<0.001$} & \multirow[t]{2}{*}{$* *$} & \multirow[t]{2}{*}{$* *$} & \multirow{2}{*}{\multicolumn{2}{|c|}{$* *$}} & \multirow[t]{2}{*}{$* *$} & \\
\hline & $\%$ & 34.7 & 59.1 & 42.6 & 41.4 & 45.9 & & & & & & & \\
\hline \multirow[t]{2}{*}{ Yes, sometimes } & $\mathrm{n}$ & 253 & 212 & 135 & 205 & 805 & & \multirow[t]{2}{*}{ ** } & & \multirow{2}{*}{\multicolumn{2}{|c|}{$* *$}} & \multirow[t]{2}{*}{$* *$} & \\
\hline & $\%$ & 59.4 & 38.2 & 54.2 & 55.4 & 50.3 & & & & & & & \\
\hline \multirow[t]{2}{*}{ No } & $\mathrm{n}$ & 25 & 158 & 12 & 60 & & & \multirow[t]{2}{*}{ ** } & & & & & \\
\hline & $\%$ & 5.9 & 2.7 & 3.2 & 3.2 & 3.8 & & & & & & & \\
\hline \multirow[t]{2}{*}{ Total } & $\mathrm{n}$ & 426 & 555 & 249 & 370 & 1600 & & & & & & & \\
\hline & $\%$ & 100.0 & 100.0 & 100.0 & 100.0 & 100.0 & & & & & & & \\
\hline
\end{tabular}

* Pearson's $\chi^{2}$ independence test

** Test for two proportions with a Bonferroni correction for multiple comparisons, $p<0.05$ 
Students belonging to clusters 2 and 4 significantly more often evaluated their diets as "very good" and less often as "rather bad", compared to students in clusters 1 and $3, p<0.05$ (Table 7).

Table 7. Subjective assessment of diet in the opinion of the surveyed students in separate clusters

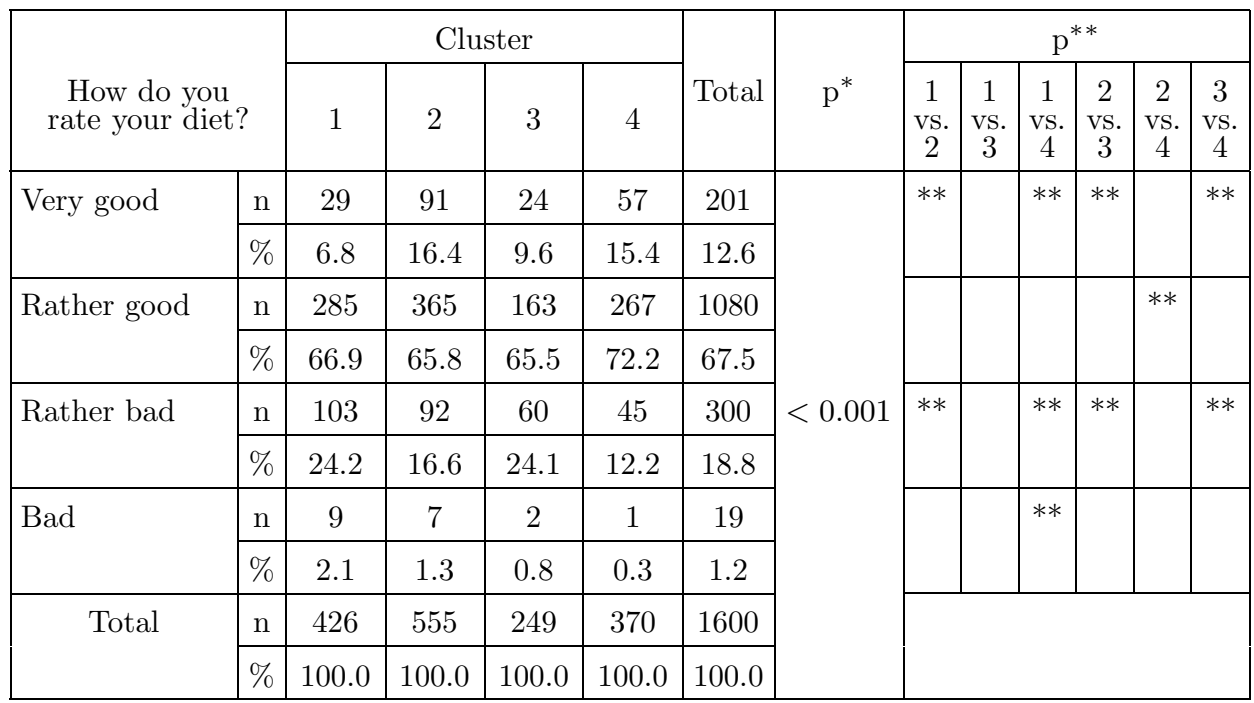

* Pearson's $\chi^{2}$ independence test

** Test for two proportions with a Bonferroni correction for multiple comparisons, $p<0.05$

All the described clusters were characterized by dietary mistakes. However, most of them were related to clusters 1 and 3 , as opposed to clusters 2 and 4 .

\section{Discussion}

Our study was designed to assess dietary habits of 18 -year-old students. We extracted clusters of them, which differed in terms of the analysed dietary behaviours. Our findings indicate the existence of many deficiencies in the nutrition of youths. Irregular consumption and omitting any of the basic meals leads to gaps between meals that are too long and promotes the formation of hunger (Mazur et al., 2008; Moreno et al., 2010). In the case of young people, the frequency of meals during a day plays an important role in the regulation of body weight (Utter et al., 2007). Consuming too small a number of meals was related to students belonging to cluster 1 , where they 


\section{Magdalena Zalewska et al.}

declared an intake of 2 or 3 meals a day. This cluster included the greatest number of students with overweight and obesity compared to other clusters and a significant proportion of girls. Another study confirms that girls more often reduce the number of meals a day and eat meals more irregularly than boys (Wanat et al., 2011).

Frequent eating promotes eating smaller portions at a time, which supplies less energy and maintains better body weight (Koletzko et al., 2010; Toschke et al., 2009). Research carried out among 16-year-olds confirmed that eating five meals a day is associated with a reduced risk of overweight/obesity in both sexes and abdominal obesity in boys (Jääskeläinen et al., 2013). A regular consumption of five meals a day causes the body to be used to a continuous supply of the appropriate doses of energy and nutrients, allowing it to reasonably administer them. When a person eats every 3-4 hours, the body does not need to over-accumulate stocks to adjust for longer periods of starvation. During gaps between meals that are too long a body can lower its metabolic rate, which causes the energy supply to accumulate with the subsequent meals. Another shortcoming is the combination of lunch with dinner as one meal and consumption of it in the late afternoon or evening, which is common in adolescents (Batyk, 2012). Research conducted by Piotrowska et al. (2009) suggested that the correct intervals between meals were observed in only $2.7 \%$ of eighteen-year-old girls. According to our research, the students did not keep the recommended intervals between meals, which was the most visible in clusters 1 and 3 . The maximum interval between meals in cluster 3 was 8 hours and 24 minutes.

Another phenomenon popular among school children was eating during the night. Research published by Kolarzyk et al. indicated that during the time period of their study the habit of night eating affected $33.9 \%$ of high school girls. The most popular night snacks included: fruit, yoghurt, candies, dinner leftovers and sandwiches (Kolarzyk et al., 2007). Similarly, we also noticed snacking during the night, and the minimum night interval was only 6-7 hours.

Proper distribution of meals during a day is essential for the proper functioning of the whole body. This results in better utilization of nutrients. The intervals between meals should not be longer than 3-4 hours. Meanwhile, in a study conducted with junior high school students, the average intervals between meals were around five hours and the variability of these values was characterized by the rule: the more meals, the shorter the interval (Maksymowicz-Jaroszuk et al., 2010). The analysis of intervals between meals carried out in this work pointed out breaks that were too long. The average interval was 5 hours and 54 minutes in the case of students 
belonging to cluster $1 ; 5$ hours and 12 minutes in cluster 2 . The average interval observed in cluster 3 was 6 hours and 18 minutes. Only in cluster 4 was the average interval between meals 3 hours and 28 minutes.

Food eaten between meals, without control over its type and quantity, can easily lead to an excess of energy in the body, resulting in weight gain and obesity. Young people who do not have their first breakfast before going to school are most often involved in snacking between meals. According to research conducted by the Institute of Food and Nutrition, approximately $10-20 \%$ of students reported that they did not consume $1^{\text {st }}$ breakfast before going to school, and some also did not take their $2^{\text {nd }}$ breakfast with them (Wolnicka, 2008). In these studies, lack of eating $1^{\text {st }}$ breakfast was noted for the greatest percentage of students belonging to cluster 1 , and the lack of $1^{\text {st }}$ and $2^{\text {nd }}$ breakfast were recorded for the greatest percentage of students belonging to cluster 3 . These were the clusters with the highest percentages of students with impaired nutritional status.

Incorrect nutrition of youth attending school includes skipping basic meals, which is confirmed by our study. Skipping tea time affected $68.1 \%$ and $21.4 \%$ of the respondents. Students belonging to clusters 1 and 3 less often consumed tea time meals than those belonging to clusters 2 and 4 . In cluster 1, almost half declared not eating supper. The irregularity of meals regarding supper was confirmed in a study conducted by Marcysiak et al. (2009) who showed that one third of surveyed students eat supper irregularly, and $19 \%$ just before bedtime. As the reports indicate, there is a significant increase in the percentage of young people with excess body weight (Jarosz et al., 2010). In the majority of studies investigated it was found that boys are more often found to have excess body weight than girls (Kułaga et al., 2011; Sweeting, 2008). In Poland, according to the HBSC 2009/2010 study, excess body weight was observed in $10 \%$ of girls and $17 \%$ boys (Currie et al., 2012). In the group of examined students, malnutrition often involved girls and overweight and obesity were related to boys.

Although adolescents do not conform to the principles of rational eating, they appreciate their diet. This was proven by research conducted by Sygit (2006) among the youth in Szczecin. As many as 23.8\% rated their diet as very good, $61 \%$ - as good, and only $1.6 \%$ as bad. This was similar to our findings but students belonging to cluster 1 most negatively evaluated their dietary habits. In the research conducted by Kolarzyk et al. (2007) it was stated that that only $34.7 \%$ of high school students rated their diet as regular. The fact that, in the opinion of young people, regularly consuming meals throughout the day is not related to health and proper body weight, 
should be considered disturbing. Although the surveyed students assessed their diets mostly as very good $(12.6 \%)$ or good $(67.5 \%)$ the results suggest a lack of knowledge of the principles of nutrition among 18-year-olds.

There were significant differences in the diets of surveyed students with proper nutritional status (clusters 2, 4) and students with impaired nutritional status (malnutrition, overweight, obesity) (clusters 1,3) in terms of the number of meals and the regularity of their consumption. According to our research, the consumption of 4 or 5 meals at the correct intervals can be regarded as a protective factor against impaired nutritional status. This has been confirmed by other reports, stressing that during the processes of body mass regulation the frequency of meals during the day plays an important role (Bachman et al., 2011; Utter et al., 2007; Wolnicka, 2008). Due to the importance of the problem from the public health point of view, the impact of diet on nutritional status disorders in children and adolescents should be monitored using statistical methods.

\section{Conclusions}

The use of cluster analysis applied to processed data regarding different times of food intake enabled the identification of nutritional problems occurring in the examined population. The major flaws in nutrition of a qualitative nature may include irregular eating, skipping meals, and eating in a hurry or in states of emotional discomfort. Over time, nutritional mistakes in the dietary habits of youths can become habits themselves. Shaping proper dietary habits is an essential element in the prevention of lifestyle diseases. This requires constant monitoring, conducting prevention programs, regular supervision and therapeutic interventions implemented at every stage of health education.

\section{R E F E R E N C E S}

Bachman, J., Phelan, S., Wing, R., \& Raynor, H. A. (2011). Eating frequency is higher in weight loss maintainers and normal-weight individuals than in overweight individuals. J Am Diet Assoc, 111(11), 1730-1734.

Bagińska, J., \& Rodakowska, E. (2012). Knowledge and practice of caries prevention in mothers from Bialystok, IJCRIMPH, 4(4), 257-266.

Baker, J., Farpour-Lambert, N., Nowicka, P., Pietrobelli, A., \& Weiss, R. (2010). Evaluation of the overweight/obese child-practical tips for the primary health care provider: Recommendations from the Childhood Obesity Task 
Force of the European Association for the Study of Obesity. Obes Facts, 3, $131-137$.

Batyk, I. (2012). Zwyczaje żywieniowe wśród młodzieży. J Health Sci, 2(5), 7-13.

Currie, C., Zanotti, C., Morgan, A., Currie, D., de Looze, M., Roberts, C., Samdal, O., et al. (Eds.). (2012). Social determinants of health and well-being among young people. Health Behaviour in School-aged Children (HBSC) study: international report from the 2009/2010 survey (Health Policy for Children and Adolescents, No. 6). Retrieved from WHO Regional Office for Europe, Copenhagen website: http://www.euro.who.int/__data/assets/pdf_ file/0003/163857/Social-determinants-of-health-and-well-being-amongyoung-people.pdf.

Jarosz, M., \& Rychlik, E. (2010). Epidemia otyłości - jaka przyszłość nas czeka? Gastroenterol Pol, 17(1), 47-52.

Jääskeläinen, A., Schwab, U., Kolehmainen, M., Pirkola, J., Järvelin, M. R., \& Laitinen, J. (2013). Associations of meal frequency and breakfast with obesity and metabolic syndrome traits in adolescents of Northern Finland Birth Cohort 1986. Nutr Metab Cardiovasc Dis, 23(10), 1002-1009.

Kardasz, M., \& Pawłowska, D. (2008). Wpływ otyłości w dzieciństwie na przyszłe życie człowieka dorosłego. Nowa Pediatr, 2, 35-40.

Kolarzyk E., \& Stop-Lewandowska A. (2007). Charakterystyka wybranych zachowań żywieniowych krakowskich studentów kierunków medycznych oraz licealistek. Żyw Człow Met, 54(1-2), 264-273.

Koletzko, B., \& Toschke, A. (2010). Meal patterns and frequencies: do they affect body weight in children and adolescents? Crit Rev Food Sci Nutr, 50(2), 100-105.

Krawczyńska, J., Karakiewicz, B., Zięba, E., \& Nowak-Starz, G. (2013). Ocena stanu zdrowia młodzieży w świetle wybranych wskaźników zdrowia. MONZ, $19(2), 193-199$.

Kułaga, Z., Litwin, M., Tkaczyk M., Palczewska, I., Zajączkowska, M., Zwolińska, D., Krynicki, T., et al. (2011). Polish 2010 growth references for schoolaged children and adolescents. Eur J Pediatr, 170, 599-609.

Maksymowicz-Jaroszuk, J., \& Karczewski, J. (2010). Ocena zachowań i zwyczajów żywieniowych gimnazjalistów z terenu Białegostoku. Hyg Publ Health, 45(2), $167-172$.

Marcysiak, M., Ciosek, A., Żywica, M., Prządak, E., Banasiewicz, D., Marcysiak, M., Zagroba, M., et al. (2009). Zachowania żywieniowe i aktywność fizyczna uczniów klas sportowych i ogólnych w Ustrzykach Dolnych. Probl Piel, 17(3), 216-222.

Mazur, A., \& Małecka-Tendera, E. (2008). Sytuacja szkolna w odniesieniu do ryzyka powstania otyłości oraz możliwości prewencji i leczenia. Stand Med, 5(2), 136-140. 


\section{Magdalena Zalewska et al.}

Moreno, L., Rodriguez, G., Fleta, J., Bueno-Lozano, M., Lazaro, A., \& Bueno, G. (2010). Trends of dietary habits in adolescents. Crit Rev Food Sci. Nutr, 50(2), 106-112.

Ng, M., Fleming, T., Robinson , M., Thomson, B., Graetz, N., Margono, C., Mullany, E. C., et al. (2014). Global, regional, and national prevalence of overweight and obesity in children and adults during 1980-2013: a systematic analysis for the Global Burden of Disease Study 2013. Lancet, S01406736(14), 60460-60468.

Ogden, C. L., Caroll, M. D., Kit, B., \& Flegal, K. M. (2012). Prevalence of Obesity in the United States, 2009-2010, NCHS Data Brief, 82, 1-7. Retrieved from http://www.cdc.gov/nchs/data/databriefs/db82.pdf.

Pelone, F., Specchia, M., Veneziano, M., Capizzi, S., Bucci, S., Mancuso, A., Ricciardi, W., et al. (2012). Economic impact of childhood obesity on health systems: a systematic review. Obes Rev, 13(5), 431-440.

Piotrowska, E., Żechałko-Czajkowska, A., Biernat, J., \& Mikołajczyk, J. (2009). Ocena wybranych cech stylu życia kształtujących stan zdrowia 16-18 letnich dziewcząt. Cz. I. Stosowanie różnych diet, aktywność fizyczna, palenie papierosów i picie alkoholu. Rocz Państw Zakt Hig, 60(1), 51-57.

Ponczek, D., \& Olszowy, I. (2012). Styl życia młodzieży i jego wpływ na zdrowie. Probl Hig Epidemiol, 93(2), 260-268.

Speiser, P., Rudolf, M., \& Anhalt, H. (2005). Consensus statement: childhood obesity. J Clin Endocrinol Metab, 90, 1871-1887.

Sweeting, H. (2008). Gendered dimensions of obesity in childhood and adolescence. Nutr J, 7, 1-14.

Sygit, K. (2006). Zwyczaje żywieniowe uczniów szkół ponadgimnazjalnych. $Z d r$ Publ, 116(1), 147-148.

Toschke, A., Thorsteinsdottir, K., \& von Kries R. (2009). GME Study Group. Meal frequency, breakfast consumption and childhood obesity. Int $J$ Pediatr Obes, $4(4), 242-248$.

Utter, J., Scragg, R., Mhurchu, C., \& Schaaf, D. (2007). At-home breakfast consumption among New Zeeland children: association with body mass index and related nutrition behaviors. J Am Diet Assoc, 107(4), 570-576.

Wanat, G., Stolarczyk, A., Grochowska-Niedworok, E., \& Kardas, M. (2011). Badania nad edukacją żywieniową i poziomem wiedzy o racjonalnym żywieniu uczniów gimnazjum. Hyg Publ Health, 46(3), 376-380.

WHO (2012). Obesity and overweight. Retrieved from http://www.who.int/media centre/factsheets/fs311/en/index.html.

Wolnicka, K. (2008). Regularne spożywanie posiłków, pojadanie między posiłkami. In M. Jarosz (Ed.), Zasady prawidtowego żywienia dzieci i młodzieży oraz wskazówki dotyczace zdrowego stylu życia (pp. 45-52). Warszawa, Polska: Instytut Żywności i Żywienia. 